\begin{tabular}{|l|l|l|}
\hline JURNAL TEKNOLOGI TERPADU VOL. 9 NO. 1 & APRIL 2021 & ISSN: 2338 - 66649 \\
\hline Received: Februari 2021 & Accepted: Maret 2021 & Published: April 2021 \\
\hline
\end{tabular}

\title{
Rancang Bangun Sistem Mini Pembangkit Listrik Tenaga Surya (PLTS) Portable
}

\author{
Randis $^{1^{*}}$, Syaeful Akbar ${ }^{2}$ \\ 1*,2 Jurusan Teknik Mesin, Politeknik Negeri Balikpapan \\ randis@poltekba.ac.id
}

\begin{abstract}
Energi alternatif merupakan salah satu solusi tepat dalam pemenuhan energi listrik yang bersumber dari bahan bakar fosil karena dipandang energi terbarukan dan ramah lingkunan. Tujuan dari penelitian ini adalah melakukan perancangan dan membuat suatu perangkat mini portable PLTS untuk petani dan nelayan di daerah terpencil. Penelitian ini dilakukan dengan melakukan perancanan dan pembuatan alat. Selanjutnya dilakukan pemgukuran tegangan dan arus pada outrput ke lampu DC dan port charger HP. Hasil penelitian menunjukkan alat dapat bekerja dengan baik dengan mampu menyalakan perangkat lampu DC dan mencharger HP pada perangkat outpunya. Hasil pengukuran pada output terminal lampu DC menunjukkan tegangan yang dihasilkan berkisar pada 12,44 - 12,54 Volt sementara untuk arus konstan pada 0,86 Ampere. Sementara pengukuran pada terminal charger HP diperoleh 4,95 - 5,2 Volt dan arus konstan pada nilai 0,54 Ampere.
\end{abstract}

Kata kunci: Energi alternatif, Lampu DC, Pembangkit listrik tenaga surya (PLTS)

\begin{abstract}
Abstrak
Alternative energy is one of the right solution to fulfillment of electrical energy that is sourced from fossil fuel since it is viewed renewable energy and environmental friendly. The aim of this research is doing the design and making a device mini portable PLTS for farmes and fishermen in remote areas. This research did with the planning and made the tool. Then, did the measurement voltage and current on output to DC lamp and port charger HP. The result of this research showed that the tool can work well with able to light DC and charge HP on the device output. The result of the measurement in output of terminal lamp DC showed the voltage was produced about 12,44-12,54 Volt while for a current of constant on 0,86 Ampere. Whereas, the measurement on charger terminal HP obtained 4,95-5,2 Volt and the constant current of 0,54 Ampere.
\end{abstract}

Keywords: Alternatif Energy, DC Lamp, Solar Power Generation 


\section{Pendahuluan}

Ketergantungan terhadap energi listrik saat ini semakin meningkat tajam, baik dari sektor industri, perkantoran, perumahan dan rumah tangga membutuhkan listrik. Energi listrik nbanyak digunakan untuk usaha dan menunjang aktivitas masing-masing seperti para nelayan, petani dan pemilik kebun yang membutuhkan penerangan untuk mendukung proses kerja mereka. Kebutuhan listrik di atas kapal bagi nelayan sangat penting guna mempermudah proses penangkapan ikan di malam hari [1].

Namun peningkatan kebutuhan listrik ini tidak sebanding dengan ketersediaan listrik yang ada dan justru akan semakin berkurang jika tidak ada cara untuk mengantisipasi hal tersebut. Penggunaan energi dari bahan bakar gas, diesel dan batu bara saat ini tidak efektif karena energi ini akan habis, harganya mahal dan tentu saja tidak ramah lingkungan serta tidak dapat diperbaharui [2].

Pengembangan sistem pembangkit listrik dengan pemanfaatan energi lain selain bahan bakar diperlukan guna menunjang kebutuhan listrik masyarakat. Sistem pembangkit listrik tenaga surya (PLTS) merupakan suatu resolusi dalam menangani masalah ini. Pemanfaatan energi surya ini termasuk ke dalam energi terbarukan, ramah lingkungan dan tidak menimbulkan polusi [3-4]. Daerah tropis seperti Indonesia memiliki potensi besar dalam mengubah energi matahari menjadi energi listrik karena letak geografis Indonesia yang berada di garis khatulistiwa sehingga Indonesia menerima sinar matahari yang berkesinambungan sepanjang tahunnya. Untuk mengubah sinar matahari menjadi energi lain kita dapat memanfaatkan bantuan alat yang bekerja berdasarkan proses photovoltaic yaitu berupa solar cell (sel surya) maupun collector.

Penerapan PLTS sebagai sumber energi listrik alternatif bagi masyarakat telah banyak dikembangkan untuk beberapa penelitian saat ini seperti pada penelitian [5] penggunaan sel surya disatukan dengan tenaga angin sebagai pembangkit listrik hanya terpusat pada kebutuhan listrik rumah tangga saja sehingga model sistem pembangkit harus terpasang permanen di area sekitar rumah. Hal ini tidak efektif dan efisien terutama bagi masyarakat yang bekerja di luar rumah seperti nelayan, petani / pemilik kebun. Terdapat juga penelitian yang memanfaatkan energi matahari sebagai pembangkit listrik untuk menggerakkan pompa air [6] dan sebagai lampu pengatur lalu lintas [7] saja.

Penelitian lain yang dilakukan [8] yang memanfaatkan energi surya sebagai sumber energi listrik yang digunakan untuk penerangan jalan di Dusun Nglingo, Kabupaten Kulonprogo, Yogyakarta yang masih minim listrik. Dalam penelitian tersebut beberapa titik-titik jalan dilakukan pemasangan panel-panel surya untuk penerangan jalan. Serupa dengan penelitian [9] juga menggunakan panel surya guna memenuhi kebutuhan listrik masyarakat di daerah terpencil sementara penelitian lainnya [10] memanfaatkan panel surya untuk mensuplai energi listrik pengering pupuk milik petani juga untuk kebutuhan listrik rumah tangga petani.

Hasil penelitian sebelumnya menunjukkan penggunaan panel-panel surya sebagai sumber energi listrik alternatif bersifat permanen sehingga pemakaiannya kurang efisien karena unit/alat tidak tidak dapat dipindahkan maupun dibawa kemana saja. Berbeda dengan penelitian ini, model (prototype) yang dikembangkan bersifat lebih fleksibel. Model sel surya sebagai pembangkit listrik ini memiliki dimenssi yang kecil (mini) dan dapat dipindahkan-pindahkan juga dibawa kemana saja (portable), dapat dimasukkan ke dalam tas ransel sehingga akan lebih memudahkan penggunanya. Prototype ini dapat diisi dayanya saat siang hari dan di malam hari dapat digunakan sebagai penerangan maupun mengisi daya baterai ponsel penggunanya.

Dalam penelitian ini, penggunaan sel surya (solar cell) dianggap lebih efektif untuk membantu individu seperti petani/pemilik kebun dalam memenuhi kebutuhan listrik di malam hari karena sel surya bekerja optimal 
dan langsung mengkonversikan sinar matahari ke energi listrik.

\section{Metodologi}

Perancangan sistem alat yang dikembangkan dibagi menjadi dua bagian yaitu sistem alat secara keseluruhan dan sistem untuk melakukan pengukuran output dari alat yang telah dibuat.

\section{a. Perancangan sistem Alat mini PLTS}

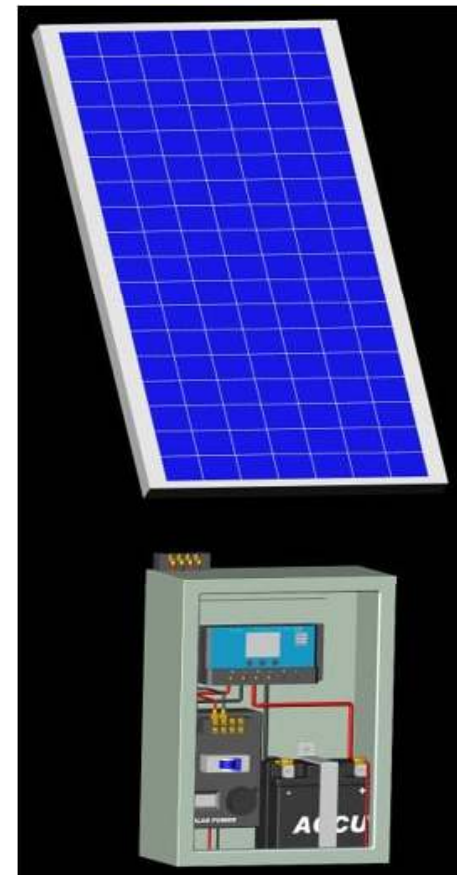

Gambar 1. Perancangan alat yang dikembangkan

Perancangan alat yang dibuat diperlihatkan pada Gambar 1. Komponen utama ditempatkan pada box panel sehingga aman dari benturan dan air, ukuran box panel yang digunakan yaitu $(35 \times 35 \times 12)$ memiliki ukuran yang lumayan kecil sehingga dapat dibawa ke mana-mana dengan menggunakan tas ransel atau semisalnya, box panel dilengkapi dengan perankat/media cantolan (Gambar 2) untuk memudahkan pengguna dalam membawa alat ini kemana-mana sehingga mobilitas alat ini cukup tinggi.

Beberapa komponen utama yang ditempatkan pada box panel yaitu baterai, controller, Voltmeter, MCB, output berupa colokan charger yang sudah dirakit dan ditempatkan pada box kecil, sementara untuk input berupa tenaga dari panel solar cell juga dibuatkan terminal dalam box panel sehingga dapat memudahkan pengguna jika ingin digunakan, begitu juga dengan output ke lampu DC juga disediakan terminal yang dapat digunakan kapan saja jika diperlukan (Gambar 2).

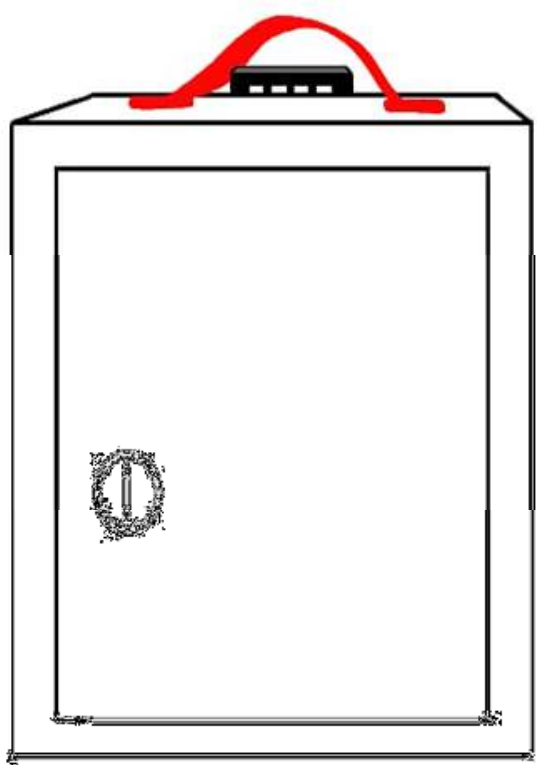

Gambar 2. Box panel yang digunakan dengan terminal dan perangkat jinjing untuk memudahkan mobilitas

Komponen alat yang digunakan dengan fungsinya masing-masing yaitu: Panel Surya sebagai sumber energi listrik untuk mengisi baterai, baterai sebagai sumber energi, voltmeter untuk mengetahui tegangan masukan dari solar cell ke baterai. Terdapat kompenen penunjang seperti controller untuk memutus pasokan energi listrik dari solar cell ke baterai jika baterai sudah penuh, MCB berfungsi untuk memutus arus dan tegangan jika terjadi hubung singkat dan beban lebih dan terakhir adalah terminal output untuk digunakan ke beban baik berupa lampu DC ataupun peralatan lainnya, dan juga terdapat port khusus untuk melakukan pengisian daya ponsel yang sangat praktis dan efektif.

\section{b. Perancangan alat ukur untuk mengukur tegangan dan arus pada alat mini PLTS}

Perancangan alat ukur ini dimaksudkan untuk mengukur tegangan dan arus keluar ke beban, baik ke beban lampu DC, beban perangkat 
colokan HP, serta pergerakan tegangan pada baterai Ketika diisi dengan solar cell. Schematic diagram pengukuran diperlihatkan pada Gambar 3. Perangkat alat ukur yang digunakan yaitu ACS 712 untuk mengukur arus sedangkan untuk mengukur tegangan sedangkan untuk mikrokontrollernya menggunakan Arduino uno dengan Bahasa pemrograman $\mathrm{C}$ [12] yang dihubungkan dengan perangkat $\mathrm{PC}$ atau laptop untuk menampilkan hasil pembacaan.

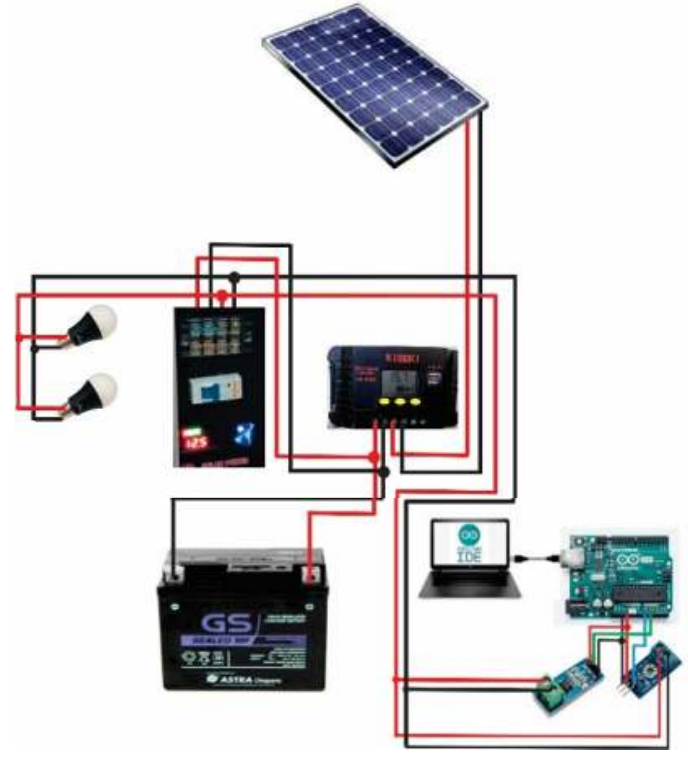

Gambar 3. Perancangan sistem alat ukur tegangan dan arus pada alat yang dibuat

\section{Hasil dan pembahasan}

\section{a. Implementasi dan prinsip kerja alat}

Secara sederhana alat yang telah dibuat dan dikembangkan diperlihatkan pada Gambar 4. Alat ini memiliki dimensi yang kecil dan sederhana serta praktis sehingga dapat dibawa kemana-mana sesuai dengan kebutuhan.

Secara prinsip kerja, alat ini akan mendapatkan suplay energi listrik dari panel solar cell pada siang hari, energi listrik akan tersimpan pada perangkat baterai, sebagai pengaman digunakan perangkat controller untuk memutus pasokan energi listrik dari panel solar cell jika pada baterai sudah penuh sehingga tidak terjadi over kapasitas, over kapasitas sendiri pada baterai dapat menyebabkan baterai cepat rusak.

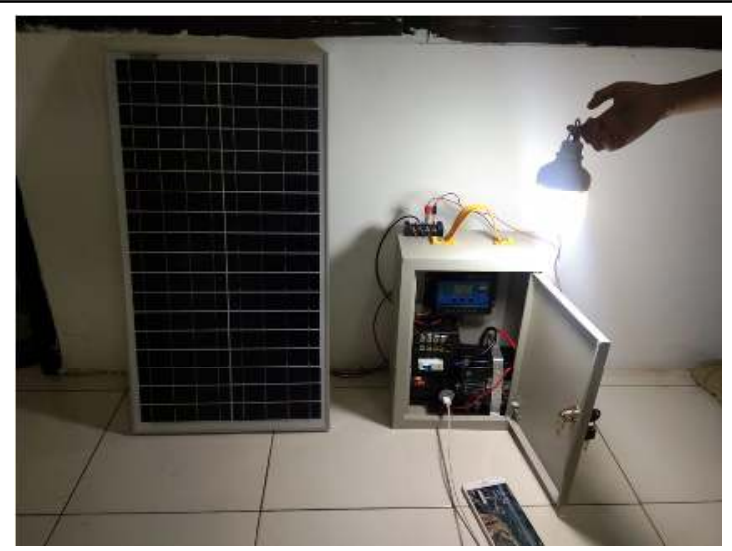

Gambar 4. Pengujian alat mini PLTS yang dibuat

Output tegangan untuk menghidupkan perangkat lampu DC dapat diperoleh dari terminal controller, terminal box pada voltmeter dan terminal yang terdapat pada luar box panel. Sedangkan output untuk melakukan charger HP terdapat pott khusus yang telah disediakan yang terdapat pada box voltmeter. Untuk keamanan sistem alat secara keseluruhan terdapat $\mathrm{MCB}$ dimana alat ini dapat digunakan sebagai on/off juga sebagai pengaman jika tejadi hubung singkat atau arus lebih.

\section{b. Hasil pengukuran pada terminal output}

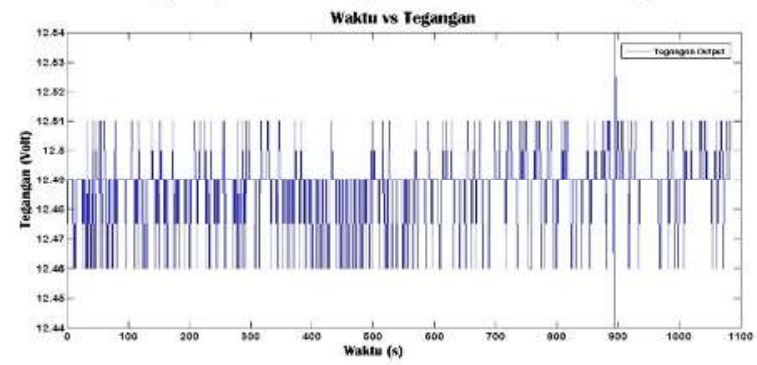

Gambar 5. Tegangan pada terminal output

Pada Gambar 5 menunjukkan pengukuran tegangan pada terminal output, data menunjukkan tegangan yang terjadi antara pada range tegangan 12,44 - 12,54 Volt dengan jumlah data sekitar 1.086 data pada rentang waktu 1.086 detik. Hal ini sudah sesuai dengan hasil pengukuran pada terminal aki. Sementara untuk arus konstan di 0,86 Ampere sebagaimana pada Gambar 6, hal ini pada kondisi tanpa beban. 


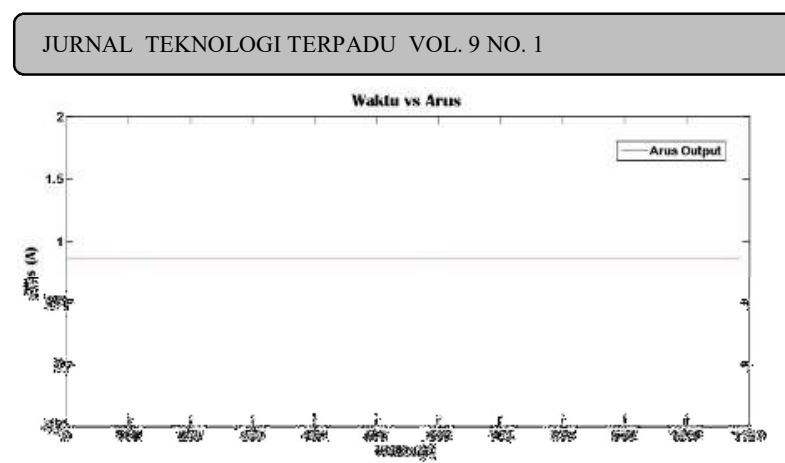

Gambar 6. Tegangan pada terminal output

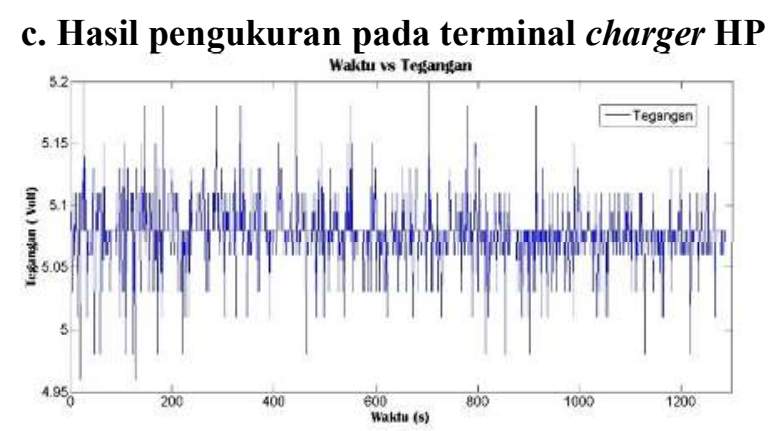

Gambar 7. Tegangan pada terminal output

Pada Gambar 7 menunjukkan pengukuran tegangan pada port charger HP, hasil pengukuran menampilkan tegangan bervariasi pada tegangan 4,95 - 5,2 Volt selama durasi waktu 1.286 detik, hal ini dianggap masih wajar dimana rentan tegangan masih bejarak pendek dan perangkat yang akan digunakan membutuhkan tegangan di 5 Volt sehingga masih aman untuk digunakan pada perangkat device. Sementara untuk arus konstan di 0,54 Ampere sebagaimana pada Gambar 8.

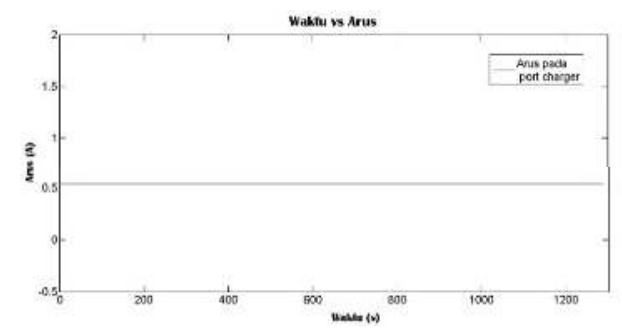

Gambar 8. Tegangan pada port charger

\section{Kesimpulan}

Penelitian ini telah berhasil menyajikan perancangan serta pembuatan sebuah mini portable PLTS yang dapat digunakan untuk mencharger HP serta menyalakan lampu DC untuk keperluan
APRIL 2021

ISSN: $2338-66649$

penerangan bagi petani, dan nelayan di daerah terpencil.

\section{Saran}

Penelitian selanjutnya dapat dikembangkan dengan melakukan pengukuran dengan mengunakan beban serta melakukan pengukuran waktu penggunaan dengan variasi beban.

\section{Daftar Pustaka}

[1] Daging, I. Ketut, et al. "Rancang Bangun Pembangkit Listrik Tenaga Surya Sebagai Sumber Listrik Untuk Kapal Perikanan Skala Kecil Di Kabupaten Pangkep, Sulawesi Selatan." Jurnal Kelautan dan Perikanan Terapan (JKPT) 2.1 (2019): 33-40.

[2] Meilani, Hilma, and Dewi Wuryandani. "Potensi Panas Bumi sebagai Energi Alternatif Pengganti Bahan Bakar Fosil untuk Pembangkit Tenaga Listrik di Indonesia." Jurnal Ekonomi \& Kebijakan Publik 1.1 (2010): 47-74.

[3] Indartono, Yuli Setyo. "Krisis Energi di Indonesia: Mengapa dan Harus Bagaimana." Majalah INOVASI 18 (2008).

[4] Manan, Saiful. "Energi Matahari, Sumber Energi Alternatif Yang Effisien, Handal Dan Ramah Lingkungan Di Indonesia." Gema teknologi (2009).

[5] Isdiyarto, Isdiyarto, Henry Ananta, and Sugeng Purbawanto. "Model pembangkit listrik tenaga angin dan surya skala kecil untuk daerah perbukitan." Sainteknol: Jurnal Sains dan Teknologi 12.1 (2014).

[6] Subandi, Slamet Hani, (2015), "Pembangkit Listrik Energi Matahari Sebagai Penggerak Pompa Air Dengan Menggunakan Solar Cell “ Jurnal Teknologi Technoscientia, 7(2): 157163.

[7] Widodo, Djoko Adi, Suryono, Tatyantoro A, (2010), "Pemberdayaan Energi Matahari Sebagai Energi Listrik Lampu Pengatur Lalu Lintas." Jurnal Teknik Elektro, 2(2): 133-138.

[8] Utari, Evrita Lusiana, Ikhwan Mustiadi, and Yudianingsih Yudianingsih. "Pemanfaatan Energi Surya sebagai Energi Alternatif 
Pengganti Listrik untuk Memenuhi Kebutuhan Penerangan Jalan di Dusun Nglinggo Kelurahan Pagerharjo Kecamatan Samigaluh Kabupaten Kulon Progo." Jurnal Pengabdian Dharma Bakti 1.2 (2018).

[9] Akhmad, Kholid. "Pembangkit Listrik Tenaga Surya dan Penerapannya Untuk Daerah Terpencil." Jurnal Ilmiah Dinamika Rekayasa 1.1 (2005): 29-33.

[10] Aryza, Solly, et al. "Implementasi Energi Surya Sebagai Sumber Suplai Alat Pengering Pupuk Petani Portabel." IT Journal Research And Development 2.1 (2017): 12-18.
[11] Akhmad, Kholid. "Pembangkit Listrik Tenaga Surya dan Penerapannya Untuk Daerah Terpencil." Jurnal Ilmiah Dinamika Rekayasa 1.1 (2005): 29-33.

[12] Mandal, S., \& Singh, D. (2017). Real Time Data Acquisation of Solar Panel Using Arduino and Further Recording Voltage of the Solar Panel. International Journal of Instrumentation and Control Systems, 7(3), 15-25. https://doi.org/10.5121/ijics.2017.7303 